\title{
A Review of the Establishment of the Stock Market in Vietnam-In Relation to other Transitional Economies
}

\author{
Hai Nguyen ${ }^{1}$, Gráinne Oates ${ }^{1} \&$ Mary Dunkley ${ }^{1}$ \\ 1 Faculty of Business and Enterprise, Accounting, Economics, Finance and Law, Swinburne University of \\ Technology, Australia \\ Correspondence: Gráinne Oates, Faculty of Business and Enterprise, Accounting, Economics, Finance and Law, \\ Swinburne University of Technology, John Street, Hawthorn, Australia. E-mail: goates@swin.edu.au
}

Received: June 11, 2014

Accepted: July 30, 2014

Online Published: August 25, 2014

doi:10.5539/ijef.v6n10p17

URL: http://dx.doi.org/10.5539/ijef.v6n10p17

\begin{abstract}
This paper critically reviews the literature on the roles of privatisation and market regulations in establishing the stock markets in transitional economies, with the focus on the case of Vietnam. Privatisation, or equitisation in Vietnam, can provide promising candidates for the stock market but can by no means replace the well-established institutions which are crucial for its long-term development. The experience from Russia, Czech Republic, Poland and China had shown that the results of mass privatisation could be frustrated if there was little transparency and investor protection on the stock market. For Vietnam, ownership in equitised State-owned Enterprises was still concentrated with the Government and the insiders, posing various risks to minority shareholders. It then required the authority to strengthen the regulatory environment to improve investor confidence.

However, enhancing regulations by imitating those of more advanced markets is not expected to bring desirable outcome for stock markets in less developed countries but instead they should focus on the ability to enforce those regulations. In Vietnam, disclosure requirements imposed on listed companies seemed to be comprehensive but not enforceable. This again reveals another drawback of the stock market in Vietnam that can disadvantage minority shareholders.
\end{abstract}

Keywords: transitional economies, share market, regulation, information disclosure, Vietnam, equitisation, privatisation, market reform

\section{Introduction}

Vietnam was the not the first country that had attempted to build a stock market on mass privatisation of State-owned enterprises (SOEs). Eastern European countries and China have supplied a great wealth of experience in how the listings of the privatised SOEs could stimulate the stock markets at an early stage. The following discussion looks into how extensive the roles of privatisation are in building the stock market of Vietnam as well as other transitional economies, which should be ideally complemented by a well-established regulatory environment.

Less than three decades ago, Vietnam was still an isolated post-war economy pursuing the centrally-commanding economic model, influenced by the Soviet Union. The economy was supported by numerous State-owned enterprises, while private businesses were almost non-existent. The weaknesses of a close and stagnant economy, the crumbling Soviet Bloc and the high growth of other economies in the region at that time had had led to the change in direction. In 1986, the $6^{\text {th }}$ National Congress of the Communist Party of Vietnam culminated in the decision to direct the economy toward market principles-"Doi Moi", one of whose contents is the establishment and development of a multi-sectorial economy. (Hoang et al., 2011). To facilitate this economic model, the country was committed to the equitisation process, which converted thousands of State-owned enterprises (SOEs) to joint-stock models. Partial ownership of these SOEs started to be sold to individual shareholders and foreign institutions, but majorly to inside managers and employees.

However, this should not be understood as the retreat of the Government in participating in the economy, but the roles of the State was unequivocally stated in the National Constitution 1992 (Article 19, Vietnam's Constitution 1992) (Note 1): 
"The State sector shall be consolidated and developed, especially in key branches and areas, and play the leading role in the national economy.

The State-run enterprises enjoy autonomy in production and trading and shall guarantee that production and trading are to yield effective results."

This special feature of privatisation in Vietnam stands in contrast with the main aim of privatisation in other countries, where the State may retreat to only their regulatory roles. The reality in Vietnam, however, reflects the socio-political objective that the country has been pursuing: constructing the Vietnamese version of a market economy, without deviating from becoming a socialist country in the long-term future. The topic is still debatable in Vietnam as to how far market principles have been applied in an economy where the State still controls the bulk of the national resources.

\subsection{Vietnam Stock Market}

The stock market has been regarded as a symbol of capitalism due to its role to support the entrepreneurial expansion within an economy. The quality of the equity market has an association with the prospective growth of a country as they encouraged private companies to be formed and expand (Levine, 1997; Levine \& Zervos, 1998). Primary markets, in particular, act as one of the channels to mobilise the idle capital among the public, annually increasing market capitalisation for secondary markets. A stock market may achieve its expected roles where there is a competition for funds between listed companies and the market forces that improve operational efficiency resulting from the diffusive ownership and takeover threats (Draho, 2004).

Vietnam, where market has been nebulous, established a stock exchange in 2000. The experience of China with a similar political and social context had shown Vietnam that market could be applied (or imposed); however playing to the market rules was a different matter. Listing on the Vietnamese stock market in the initial period was meagre and often associated with conservatism. Equitised SOEs have been the main suppliers of stock, but subjecting them to market practice involves difficulties, especially when the State still holds significant portions of ownership in these enterprises. The continuous vitality of the private sector requires a strong capital support from the stock exchange; however the short history of the sector suggests its underdevelopment and the limited ability to compete with the State companies (Wolff, 1999). Despite that, listing is still open for companies for both State and private sectors, but has Vietnam embraced the necessary fundamentals to build a stock market that can sustainably develop in the long run?

\section{Literature Review}

Previous studies have demonstrated various examples of and lessons to be learnt from economies which have had similar experience. This section begins by demonstrating the discussion on the history and the roles of privatisation in building stock markets, especially in the context of emerging markets. The following section demonstrates the arguments that support the necessity to have strong and enforceable regulations to maintain the sustainable development of the market, exemplified by the examples of Russia, Czech Republic and Poland, countries which had also built the stock markets via privatisation.

\subsection{Privatisation and Its Impact on the Stock Market}

\subsubsection{The Origin and History of Privatisation: The Global Experience}

Privatisation is known to date back to the Thatcher Government in the late 1970s (Megginson \& Netter, 2001). Since then the wave of privatisation has swept through many other parts of the world: from Western Europe, Latin America, Southeast Asia and Russia and Eastern Europe, proving to be not only viable but also an attractive policy option (Draho, 2004).

Privatisation has been a key reforming strategy in many countries, and experience has been accumulated throughout its history. However, World Bank (1992) acknowledged that "privatisation is not a blanket solution for the problems of poorly performing SOEs. It cannot in and of itself make up totally for lack of competition, for weak capital markets, or for the absence of an appropriate regulatory framework". A lesson to be learnt is that privatisation should be a part of a larger program of reforms promoting efficiency. Privatisation needs to be accompanied by the reforms to open markets, eliminate SOEs' monopoly power and encourage the development of a private sector through free entry (World Bank, 1992). Nellis (1999) illustrated an example of Czech Republic where mass privatisation generated a huge number of privatised SOEs where the controlling stake was still owned by many State-influenced banks. These banks were often found to be inefficient in promoting better management, but usually grant easy credits to high-risk, unpromising privatised firms. As a result, the financial health of these SOEs was harmed and minority investors were at risk of being expropriated by majority shareholders. 


\subsubsection{Privatisation and the Development of the Stock Market}

Privatisation in many countries has been a great source of supply of stocks for the equity market. Among the privatised SOEs, many when listed on the stock exchange have increased the size of the equity markets by multiple times (Naceur et al., 2010) . For example, market capitalization in developing countries, from 1983 to 1999 increased by twenty-six times and trading volume by twenty-nine times-an "astounding result" of privatisation as claimed by Draho (2004). Draho (2004) further highlighted that in many developing countries, the largest companies on the stock exchange was often privatised SOEs, such as Petrobas in Brazil, ChinaMobile in China and Telefonos de Mexico in Mexico.

Many countries, especially emerging countries transitioning from central economy to market economy have aimed at developing equity market together with privatisation. However, a quick and extensive privatisation program does not guarantee a successful equity market. A strong market should be preceded by a strong framework of institutions, in which market regulation is an important factor (Naceur et al., 2010). The "textbook" examples of Russia, Czech Republic and Poland were found to be covered in several studies (Nellis, 1999; Coffee Jr, 1999; Liebermann \& Kirkness, 1998) that highlighted the difference between the approaches to constructing the equity market. Transparency and information dissemination were not promoted by the regulators in Russia and Czech Republic when mass privatisation was pushing a huge number of SOEs on to the stock market. These stock markets performed well after their instigation, but failed to attract investors and listed firms in a longer term. In many privatised companies listed on the stock exchanges, ownership was concentrated, exposing minority shareholders to many risks. In contrast, Poland presents an example of a transitional economy where privatisation was conducted gradually in phases, which was complemented by the construction of necessary institutions for a long-term strong market (Coffee Jr, 1999).

\subsubsection{China's Privatisation and Experience in Listing SOEs}

Like Vietnam, China is a country where the State participates significantly and actively in the economy. Privatisation took place at the national scale in 1980s, followed by the listings of many formerly SOEs on the stock exchanges. With the stock market being treated as a tool to promote the privatisation program, IPO firms in China have been selected from the pool of successful equitised SOEs via the quota system. Howie (2011) demonstrated different aspects of this "highly bureaucratic and time consuming" process of IPO, from estimating the level of capital to be raised every year, selecting favoured industries to initially pricing the shares and which stock exchange they were to be listed on.

This centrally-commanded selection has been criticised by several authors. First it limited the opportunity for non-state companies to be listed as municipal authorities, the body entitled with nominating listing candidates, were found to be in greater favour of SOEs (Howie, 2011). This preference had shaped the form of the market where at the end of March 2006, there were only 5 out of 1349 listed companies that were $100 \%$ privately owned (Howie, 2011). In the same critical spectrum, Zhang and Ma (2012) criticised the weak legal environment which has failed to support the growth of the Chinese stock market. Among three pillars (Note 2) in consideration, "unfair offering system" has largely contributed to the unpopularity of listing activities among smaller capitalised private corporates in China, as "merit review" (the assessment of eligibility of firms prior IPOs) set too high standards for them to pass. Second, China's stock exchanges were depicted as "a fertile breeding ground for rent seeking and corruption by regulators" (Zhang \& Ma, 2012), which further highlights the lack of transparency in the operation of listing activities. This conclusion was found to be supported by Zhu (cited in Du \& Xu, 2009), who condemned this selecting practice as a "market failure" and Tian and Megginson (2007)acknowledging that the system might prompt companies well-connected with the authority, instead of those of sound quality, to go public. Third, the political favour granted by the Government induced companies to disregard market discipline, in terms of "openness, integrity and efficiency" other than at the direct administrative intervention of the China Securities Regulatory Commission (Howie, 2011). In summary, while the share market had been established in China, the centrally-commanding economy's legacies were still present in this market and unfair treatments by the Government between the State and private sectors distorted the competition for funds that should have been a prevailing factor in a healthy market.

\subsection{Vietnam's Equitisation and the Construction of the Stock Market}

Equitisation has been a nationwide program that was initiated after the 6th Congress of the Vietnam Communist Party and has been implemented via the partial sales, liquidations and merges of the State-owned Enterprises, accompanied by the creation of a private sector. Findings of studies on the equitisation of State-owned Enterprises of Vietnam have converged on the slow rate of the process (see Shimomoto, 2003; Sjöholm, 2006; World Bank, 2006). Even though the process saw some acceleration after the pilot program was finished, 
compared with the initially proposed plan, the actual advancement has been deemed sluggish.

In specifying the number of SOEs that have been equitised, the low level of publication accompanied by divergent statistics poses a difficulty, stemming from the different approaches to define State-owned Enterprises (Cheshier et al., 2006). The adapted graph below illustrates the number of SOEs that have been equitised each year and those remaining in the period between 1990 and 2005. For example, in 2000 there were 212 SOEs completing equitisation and 5519 non-equitised SOEs.

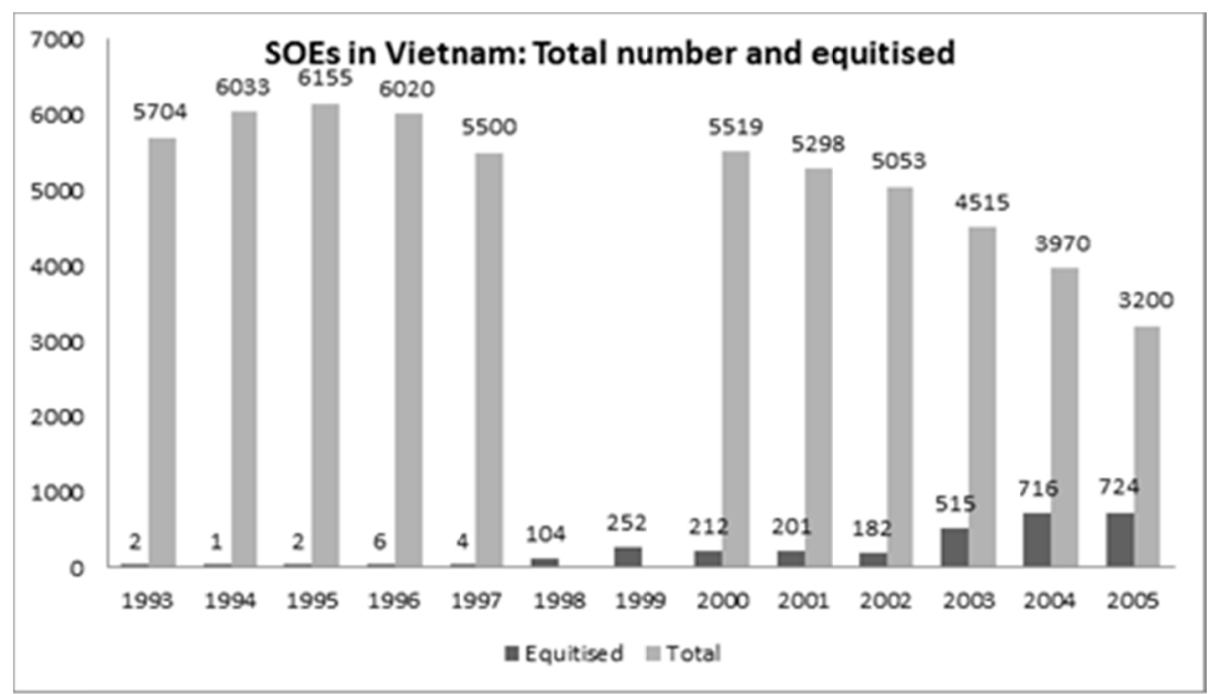

Figure 1. Number of total and equitised SOEs from 1993 to 2005

Note. Adapted from Cheshier et al. (2006) (Note 3).

The timeframe of the program is typically divided into two parts: the pilot period, from 1992 to 2000 and the acceleration period, after 2000 (Sjöholm, 2006). The pilot period encouraged the managers of SOEs to voluntarily nominate their enterprises to be equitised. As a result it was then implemented with slow progress and caution, characterised by the low determination of the management of the SOEs and the lack of experience during the conversion duration, including administrative difficulties (Sjöholm, 2006; Shimomoto, 2003). Voluntarism eventually ended in 1996 when the Government set targets for line ministries and local authorities to equitise corporations under their control. After 2000 equitisation gained momentum as the result of experience from the previous period. However this advancement was also attributed to the simplicity and relatively small size of these corporations undertaking equitisation (Sjöholm, 2006). The period between 2008 and the present (2012) has seldom been coverd by many thorough studies. Large and extricately-structure:d General Corporations (which have multiple layers of subsidiaries under their control) are expected to be equitised during this period, but the actual attainments have been frustrated by several factors including unfavourable movements of the international and local share markets and their failures to conduct IPOs ('SOE equitisation process slow going', 2009).

As shown in Table 1, even after equitisation, the Government still held a large portion of ownership of equitised companies. While there had been large companies listed, a considerable portion of their ownership have still been held by the State and locked with the managers, and therefore the number of tradable shares are much different to the number of listed shares. Most SOEs after equitisation lacked the separation between ownership and management, indicated by the tendency of many equitised SOEs' managers (often appointed by the Government) to obtain advice from their controlling governmental entities on daily operational affairs of their companies (Gainsborough, 2009). Vietnamese government has also been known for continuously granting cheap, non-collateralised loans for companies in the State sector with the incentives to create more employment, or invest in low-profitable areas (Mishra, 2011). An example was shown by Mishra (2011) where the joint stock commercial banks with the Government holding the majority ownership were likely to be instructed to issue loans to other SOEs. This has created two issues. First, the competition for funds between the private and State sector can be distorted, which was shown by the reluctance to be listed of those SOEs having access to cheap loans (Sjöholm, 2006). Second, in light of the example from Czech Republic, this can lead to a potential 
disadvantage for minority shareholders as their wealth-maximisation objectives are not always prioritised.

Table 1. Share ownership in privatised companies in Vietnam and other transitional companies

\begin{tabular}{lccc}
\hline Country & The state & Insiders & Outsiders \\
\hline Vietnam (2004) & $\mathbf{3 8 . 1}$ & $\mathbf{4 6 . 5}$ & $\mathbf{1 5 . 4}$ \\
Georgia (1997) & 23.3 & 64.4 & 12.4 \\
Kazakhstan (1997) & 16.1 & 37.6 & 46.3 \\
Kyrgyz Republic (1997) & 5.6 & 70.8 & 23.6 \\
Moldova (1997) & 23.8 & 38 & 38.2 \\
Russia (1997) & 14.7 & 59.6 & 25.7 \\
Ukraine (1997) & 15.4 & 61.5 & 23.1 \\
\hline
\end{tabular}

Source: Nguyen (2005) and Djankov (1999), cited in Truong (2006).

What remains the question here is that in comparison with other transitional markets that preceded Vietnam in constructing the share markets, how much has been promoted and implemented to introduce market principles, including the fair and transparent competition for finance. The threat of concentrated ownership has been illustrated in the previous examples, and in the case of Vietnam, concentrated ownership by a limited number of managers, employees and their relatives not only exposed many risks to the ill-informed minority shareholders, but also could easily dampen their confidence once scandals happen. As stated by Coffee Jr (1999, p. 32), “in transitional economies, it may take little to disturb investor confidence and produce a flight for the exits."

\subsection{Strong Regulatory Environment and the Sustainable Development of the Market}

Scholars have long been sceptical of regulations in controlling financial market as they deem private settlements between sophisticated investors and sophisticated issuers should generate the highest cost efficiency (Glaeser et al., 2001; Easterbrook, 1996). The growing stance nonetheless, is that regulations are necessary and have an association with the development of the equity market. For example, La Porta et al. (2001) compared the different measures as proxies for shareholders' protections across the sample of 51 countries with different legal origins. They acknowledged that countries where common law rules provided investors with greater protections, as compared to those of civil law, especially French civil law. As a result, share ownership in common law countries was more effusive as small shareholders were equipped with better legal equipment to claim their rights against the dominance of majority shareholders, and at the same time, able to diversify their portfolios.

The relationship between regulations and stock market development in emerging countries was again exemplified in the cases of Poland and Czech Republic (Glaeser et al., 2001). In this study, the more vigorous enforcement of regulations, through policing companies' compliance with disclosure and timely regulatory responses of the market maintained the high growth of the Polish market, in terms of capitalisation and investor base. Czech Republic stock market, conversely, fell into a "moribund" manner after a quick expansion after privatisation, due to the hands-off regulations and investors' frustration after constantly occurring scandals. La Porta et al. (2001) further emphasized that leaving the financial markets alone is not a good way to encourage them. "Financial markets need some protection of outside investors, whether by courts, Government agencies, or market participants themselves". (La Porta et al., 2001, p. 24). The consequence of the weak investor protections, in their view, was the underdevelopment of the share market as a funding channel compared to credit funding.

\subsection{Investor Protection and Disclosure as a Mechanism to Protect Investors}

Disclosure is the practice of acknowledging shareholders firm-related information that can affect their decisions to hold ownership of that company. Due to the separation between the management and ownership, investors should be informed of the performance of the companies under the current management. Timely dissemination of information would lead to timely and educated decision of investors to allocate their resources. Investors' rights to information are regarded as an important factor for an efficient market.

Black (2001) widely discusses a variety of institutions that contribute as preconditions to a "strong" securities market. Among them are extensive financial disclosure, accompanied by an accounting and auditing rule that address investors' need for information, and, a stock exchange with meaningful listing standards and the willingness to enforce them by fining or delisting companies that violate disclosure rules. As claimed by the author, "honest" companies residing in countries of weak institutions for financial market tend not to choose share issuance as a funding channel as weak investor protection prevents them from realising fair prices for their 
shares.

In financial regimes with strong institutions, prices of "honest" companies issuing shares are highly valued, but in turn, would encourage "dishonest" companies to issue shares. It comes down to how the institutions that work to minimise the information asymmetry should be continuously maintained to distinguish between good and bad issuers. Furthermore Black (2001) explained the importance of "culture" as a self-reinforcing factor. He emphasized the importance of having the culture in which compliance with regulations is respected and enforced:

"In a strong market, good disclosure and limited self-dealing become self-reinforcing norms because they are how most businesspeople behave, regulators can aggressively pursue the few departures from the norm, and there is political support for the funding to maintain the enforcement that reinforces the cultural norm. In a weak market, weak disclosures and extensive self-dealing become self-reinforcing norms. Many businesspeople behave this way, many of them get away with self-dealing because the regulators (even if honest and decently funded) can address only the most egregious cases, and the self-dealers oppose stronger rules or better funded regulators".

Frost et al. (2006) empirically examined the relationship between the levels of compulsory disclosure system of a sample of 50 stock exchanges with the liquidity of the markets. Their findings supported the hypothesis that the strength of disclosure system, represented by disclosure rules, monitoring and enforcement, and information dissemination channels, was positively associated with market liquidity. The findings led to the necessity to strengthen timely and credible disclosure of companies as liquidity can also have spill-over effects of attracting new listing companies and increasing investors' trading opportunities as well as enhancing their confidence. From an individual firm's perspectives, higher compulsory disclosure was found to be associated with greater liquidity of the compliant companies. For instance when a higher level of compulsory disclosure was imposed on companies listed on the OTC Bulletin Board (US) companies could either choose to comply or leave the board. Bushee and Leuz (2005) discovered that those who decided to stay and comply with the new market regulations had higher liquidity (and therefore, greater market reputation), which were considered positive externalities from more stringent disclosure requirements.

However, although mandatory disclosure is crucial, it is the question of how much disclosure is desirable. Admati and Pfleiderer (2000) acknowledged the difficulties in designing an appropriate and effective set of disclosure policies that fit all firms bearing divergent costs of disclosure due to their firm-specific parameters. There should not be a "one-case-fit-all" model of standard requirements for stock markets, but it is more important that the development of these rules be based on fundamental principles of fairness, equity and effective monitoring and enforcement (Blommestein, 2003). A problem arising from emerging markets not only lies in the construction of stringent rules and regulations but also in the lack of capacity to enforce them (Friedman \& Grose, 2006; Glaeser et al., 2001). Friedman and Grose (2006) criticised the comprehensive "best practice" benchmark proposed in the Objectives and Principles of Securities Regulation by the International Organisation of Securities Commission. For emerging markets, it is recommended that instead of building a set of rules that are "nice" (i.e., seeking to replicate the regulatory environment in more developed countries), they should concentrate on what is "necessary". In their opinion, an important feature of "an appropriately designed and effective legal and regulatory framework" is that it ensures legal certainty and provides "clearly expressed and readily understandable regulation that is accessible, easy to comply with and easy to enforce, especially given resource and other constraints." Coffee Jr (1999) cited an example of Russia, upon constructing its stock market, adopting corporate governance rules from the U.S and the U.K but "laws on paper" were far different from "laws in practice". Similarly to the Czech Republic, Russia saw its stock market become riddled with corporate scandals and investor mistrust. Friedman and Grose (2006, p. 9) concluded: "It is important for the country to develop a program of reform that will facilitate development by striking a balance between changes that are necessary in order to move towards best practice and not making too many changes that exhaust the market's appetite for reform and impede development"

\subsection{Disclosure on the Stock Market of Vietnam}

Previous studies have concentrated on the fact that disclosure has been an unfamiliar practice in Vietnam. Van (2002) claimed that out of 660 that had been equitised by 2002, only 11 were listed on the stock market, even though many others could satisfy the listing requirements. The hesitance of these 'trading-floor-ready' companies was attributed to the following reasons: (1) their fear of information disclosure and being controlled and threatened by competitors, (2) their concerns of unfamiliar shareholding structure and corporate governance of publicly listed companies, and (3) their lack of knowledge of the benefits of going public (Van, 2002). Vu 
(2012) claimed that SOEs were considered production units in the previous period of central command and the reporting responsibilities were limited to reporting their production costs including materials and labour wages, for the monitoring of the Government. According to $\mathrm{Vu}$ (2012) ruling accounting regime prior to Doi Moi was heavily influenced by that applied to the Soviet Union- what was similar to the current "cost accounting". This system differed to that used for external reporting in that SOEs lacked the incentives to obtain external auditors' opinions, the focus on budgeting and profits being treated as only a comparative reference. Even after major reforms in Accounting Principles in the period between 1990 and 2000, the main purpose of the reports was still mainly for the supervision of SOEs' production, while using financial statements of SOEs to make comparison and investment decisions was of difficulty to the users (Van, 2002; Vu, 2012). In addition, the level of disclosure by sampled firms, according to $\mathrm{Vu}$ (2012) had negative association with State ownership. The reason proposed by the author is: "State ownership represents no 'real owner' and as such, there is lack of 'real incentive' to monitor firms, thereby giving firms little motivation to disclosure more information" (p. 233).

However, following the equitisation and particularly the establishment of the first stock exchange, disclosure requirements were impressive from the very beginning (Van, 2002). Despite that, upholding them was a different matter for the regulator. According to World Bank (2006), there was not "enough assurance that information prepared and disclosed by enterprises adheres to VAS (Vietnam Accounting Standards)/ IFRS (International Financial Reporting Standards), because of the lack of an effective mechanism to monitor the quality of information, or more fundamentally, to monitor that information is prepared and disclosed at all". The report explicitly stated the reason for this: "The market regulator has been reluctant to tighten the rule too strictly in fear of deterring new listings“(World Bank, 2006, p. 23).

\section{Conclusion}

This discussion relates to how stock markets, with a focus on emerging countries and privatisation, have been constructed. Privatisation has been an important factor that gave the initial stimulus to the stock market as it often breaks the "liquidity-trap" of the market- arising from the lukewarm attitude given to the stock markets by both investors and companies seeking finance (Draho, 2004). Vietnam was committed to the direction toward market since the late 1980 by releasing a considerable amount of State ownership to the public. However the advancement was still regarded as slow and limited in achievements. Equitisation (Vietnamese version of privatisation) seemed not to be enough to gurantee a long-term healthy stock market, which also requires other institutions in a typical market economy. The loopholes lie in the large amounts of ownership still vested in the State and many insiders of equitised SOEs, which may reduce the shareholders' capacity to monitor the mangement of these SOEs and expose minority shareholders to greater risks.

The discussion also included the importance of sound institutions as a crucial factor for the healthy development of a stock market. Among these institutions are enforceable investor protections, which exert an influence on the readiness of investors to contribute their funds to this market. To realise this, disclosure is a mechanism that needs to be strongly implemented. However previous experience emphasised the needs to have not only a strict, but also enforceable set of rules, as well as the close monitoring responsibilities of the market regulators (as opposed to comprehensive rules which are difficult to comply with and administered). In the case of Vietnam, information disclosure at the start of the stock market was found to be low, which could be attributed to the unfamiliarity of equitised SOEs which used to be owned by only the government. This may represent a challenge for the sustainable development of such a market where information plays a crucial role in the decision making of the investors.

In summary, Vietnam bears many characteristics of an emerging market in the attempt to create a stock market from mass privatisation. Despite a number of achievements, the stock market in Vietnam has a long way to go before becoming an attractive funding source of listed companies and a reliable investment means for a greater number of investors. This review is convergent with many other previous studies that recommended subjecting Vietnamese SOEs to market principles as an urgent priority-in this case, on the financial market.

\section{References}

Admati, A. R., \& Pfleiderer, P. (2000). Forcing firms to talk: Financial disclosure regulation and externalities. Review of Financial Studies, 13, 479-519. http://dx.doi.org/10.1093/rfs/13.3.479

Black, B. (2001). The legal and institutional preconditions for strong securities markets. UCLA Law Review, 48, 781-855.

Blommestein, H. J. (2003). Major policy challenges in developing exchanges in emerging economies. Financial Market Trends-OECD, 85, 123-144. 
Bushee, B. J., \& Leuz, C. (2005). Economic consequences of SEC disclosure regulation: evidence from the OTC bulletin board. Journal of Accounting and Economics, 39, 233-264. http://dx.doi.org/10.1016/j.jacceco.2004.04.002

Cheshier, S., Penrose, J., \& Nguyen, T. T. N. (2006). The State as Investor: Equitisation, Privatisation and the Transformation of SOEs in Vietnam. United Nation Development Program, Hanoi.

Coffee Jr, J. C. (1999). Privatization and corporate governance: The lessons from securities market failure. The Journal of Corporation Law, 25, 1.

Draho, J. (2004). The IPO decision : why and how companies go public. Northampton, Mass: Edward Elgar Publishing.

Du, J., \& Xu, C. (2009). Which firms went public in China? A study of financial market regulation. World Development, 37, 812-824. http://dx.doi.org/10.1016/j.worlddev.2008.07.012

Easterbrook, F. H. (1996). The economic structure of corporate law. Harvard University Press.

Friedman, F., \& Grose, C. (2006). Promoting access to primary equity markets: A legal and regulatory approach. World Bank Policy Research Working Paper Series.

Frost, C. A., Gordon, E. A., \& Hayes, A. F. (2006). Stock exchange disclosure and market development: an analysis of 50 international exchanges. Journal of Accounting Research, 44, 437-483. http://dx.doi.org/10.1111/j.1475-679X.2006.00208.x

Gainsborough, M. (2009). Privatisation as state advance: Private indirect government in Vietnam. New Political Economy, 14, 257-274. http://dx.doi.org/10.1080/13563460902826013

Glaeser, E., Johnson, S., \& Shleifer, A. (2001). Coase versus the Coasians. The Quarterly Journal of Economics, 116, 853-899. http://dx.doi.org/10.1162/00335530152466250

Hoang, V. Q., Van Nhue, D., Van Houtte, D., \& Dung, T. T. (2011). The Entrepreneurial Facets as Precursor to Vietnam's Economic Renovation in 1986. The IUP Journal of Entrepreneurship Development.

Howie, F. J. T. (2011). Privatizing China: Inside China's Stock Markets (2nd ed.). Wiley.

International Finance Corporation. (2012). Vietnam Corporate Governance Scorecard 2012. Washington, United States of America: The World Bank.

La Porta, R., Lopez-De-Silanes, F., Shleifer, A., \& Vishny, R. W. (2001). Law and finance. Berlin Heidelberg: Springer.

Levine, R. (1997). Financial Development And Economic Growth: Views And Agenda. Journal of Economic Literature, 35, 688-726.

Levine, R., \& Zervos, S. (1998). Stock Markets, Banks, and Economic Growth. The American Economic Review, $88,537-558$

Liebermann, I. W., \& Kirkness, C. D. (1998). Privatization and emerging equity markets. Co-published by World Bank and Flemings, Washington US. http://dx.doi.org/10.1596/0-8213-4187-1

Megginson, W. L., \& Netter, J. M. (2001). From State to Market: A Survey of Empirical Studies on Privatization. Journal of Economic Literature, 39, 321-389. http://dx.doi.org/10.1257/jel.39.2.321

Mishra, D. (2011). Vietnam Development Report 2012: Market Economy for A Middle-income Country. Washington D.C.: The Worldbank.

Naceur, S. B., Boubakri, N., \& Ghazouani, S. (2010). Privatization and financial market development in emerging countries: A comparative study. Middle East Development Journal, 2, 229-250. http://dx.doi.org/10.1142/S1793812010000241

Nellis, J. (1999). Time to Rethink Privatization in Transition Economies? Finance \& Development, 17.

Shimomoto, Y. (2003). Developing the capital market-Vietnam. Rising to the Challenge in Asia: A Study of Financial Markets, 12, 53-72.

Sjöholm, F. (2006). State owned enterprises and equitization in Vietnam. Stockholm School of Economics working paper, 228.

SOE Equitisation Process Slow Going. (2009). VOV Online.

Tian, G. L., \& Megginson, W. (2007). Extreme underpricing: determinants of Chinese IPO initial returns. 
Truong, D. L. (2006). Equitisation And Stock-Market Development: The Case of Vietnam. University of Groningen.

Van, N. T. A. (2002). Toward A Well Functioning Securities Market In Vietnam. Nagoya University.

Vu, K. B. A. H. (2012). Determinants of Voluntary Disclosure for Vietnamese Listed Firms. PhD Thesis, Curtin University, Perth WA Australia.

Wilson, D., \& Stupnytska, A. (2007). The N-11: More than an acronym. Global Economics Paper No. No: 153. GS Global Economic Website: Goldman Sachs.(Next-11).

Wolff, P. (1999). Vietnam: The Incomplete Transformation. Taylor \& Francis.

World Bank. (1992). Privatization: eight lessons of experience. World Bank. Retrieved from http://www.worldbank.org/html/prddr/outreach/or3.html

World Bank. (2006). Corporate Governance Country Assessment: Vietnam. Report on the Observance of Standards and Codes. Vietnam: The World Bank.

Zhang, L., \& Ma, B. (2012). Legal Reflections on China's Stock Market. International Business \& Management, $5,62-66$.

\section{Notes}

Note 1. Equitisation has been the Vietnamese term for privatisation. "Privatisation" has still been avoided to be mentioned due to its political connotation.

Note 2. Zhang and Ma (2012) considered the sluggish development of the share market in China as the consequence of the failure to enhance three pillars that form the legal system of the security market: the public offering system, the civil liability system and fiduciary system.

Note 3. Quoted numbers are the averages of statistical results of different studies cited in Cheshier et al. (2006). No figure related to the outstanding SOEs was reported in 1998 and 1999.

\section{Copyrights}

Copyright for this article is retained by the author(s), with first publication rights granted to the journal.

This is an open-access article distributed under the terms and conditions of the Creative Commons Attribution license (http://creativecommons.org/licenses/by/3.0/). 